\title{
DESIGN OF A WOOD CUTTING MACHINE
}

\author{
Norbert HODGYAI, ${ }^{1}$ Attila GERGELY ${ }^{2}$ \\ Sapientia Hungarian University of Transylvania, Faculty of Technical and Human Sciences Târgu Mureș, \\ Târgu Mureș, Romania \\ ${ }^{1}$ hodgyainorbi@gmail.com \\ 2agergely@ms.sapientia.ro
}

\begin{abstract}
The price of firewood has increased substantially in the last couple of years due to the high volume of export. The branches and smaller diameter pieces are considered leftovers and are not exportable, however they are suitable as firewood. Chainsaws are used to cut the larger diameter wood, but this way is not efficient for cutting up branches and smaller diameter wood pieces. In this paper we present the structure, working principle and the 3D model of a machine that can be used to chop smaller diameter wood branches in a simple and efficient way.
\end{abstract}

Keywords: kinematic chain, branch chopping, wood cutting, design, 3D modeling.

\section{Introduction}

Firewood is prepared to the desired size by chain or circular saw, however these machines are not effective for branches with smaller diameters. In order to solve this problem, branch cutter and chopper machines have been developed which provide a quick and energy efficient solution.

Wood chopper machines produce wood chips with dimension in the couple of $\mathrm{cm}$ range that can be stored in bags. This procedure has high energy requirements, and additionally the storage of the bagged wood chips requires special conditions if the aim is to use it for heating purposes. The wood chips have to dry before being used as firewood, however packaging it in bags partially prevents this. Bagged wood chips become biomass over time.

Wood cutter machines, on the other hand, produce wood pieces in the $20-30 \mathrm{~cm}$ range, which allows for easier storage, furthermore, wood at these dimensions dries out easily. A further advantage of this method is the low energy requirement, since in contrast with the wood chopper (which requires a lot of cuts to transform the wood into small chips) only a few cuts are needed to produce wood pieces that have an approximate length of $30 \mathrm{~cm}$.

There are different type of wood cutting machines on the market with either one or three shaft construction. The working principle is very similar in both types: 3 or 4 blades are mounted on one or two shafts that perform the cutting action. The drivetrain of these instrument is determined by the required mobility constraints on the instrument. These drivetrains could be electric motors, when mobility is not important, it could be a small two stroke engine that could be transported easily for improved mobility, however it has to be noted that this solution is only viable for smaller branch diameters, like bushes or similar. For heavy duty lumbering, tractors are used to power the machines. Some designs have a feeding system, however the three shaft type does not require a feeding system, meaning that due to the rotary motion, and the positioning of the blades, it pulls the branch into the machine. 


\section{The designed wood cutting machine}

\subsection{Input data}

In designing the wood cutting machine we first selected the type: the three-shaft design, secondly, we had to consider that the gears were already in our possession', and last that the machine has to be powered by a UTB 445dt tractor. Our next most important criteria was cost effectiveness, thus we tried to use standardized components where ever possible, for fast and easy repairability.

The machine has three shafts, one is the driving shaft, and the two others are the cutting shafts that are equipped with blades. The tractor drives the driving shaft that is connected to the first cutting shaft with a high reduction ratio, thus producing substantial torque. The first cutting shaft drives the second cutting shaft by gear pair that have a gear ratio of 1 . Thus, through the rotary motion, the blades on the two shafts rotate in such a way that the gap between them decreases to a minimum of less than $5 \mathrm{~mm}$, thus causing the captivated wood to shear apart.

The wood cutting machine is powered by a drive shaft that is connected to both the machine and the tractor through a TLT type spline shaft. In the planning process we used the 1987 built UTB 445dt type tractor specification that is equipped with a D115 type engine, with the result that when the engine rotates at $1967 \mathrm{rpm}$ the spline shaft rotates at $540 \mathrm{rpm}$. At $1500 \mathrm{rpm}$ the engine produces $146.11 \mathrm{Nm}$ torque, and $411,79 \mathrm{rpm}$ at the TLT spline shaft. [1]

\subsection{Structure of the machine}

\subsubsection{The frame}

The housing is made of $16 \mathrm{~mm}$ thick OL50 material which is connected and fixed by the screws. The metal sheets have dimensions of $480 \mathrm{~mm} \mathrm{x}$ $980 \mathrm{~mm}$. The holes that are needed to connect the bearing housings are required to be manufactured with high precision, since these will determine the distance between the two cutting shafts that are connected by gears. The distance between the gears is essential in order to be accurate. The bearing houses are connected to the metal sheets by DIN7968 screws. [2]

\subsubsection{Spline shaft}

The dimension of the spline shaft was determined by accounting for the surface compression stress at the maximum torque value. During the calculations we assumed that under working

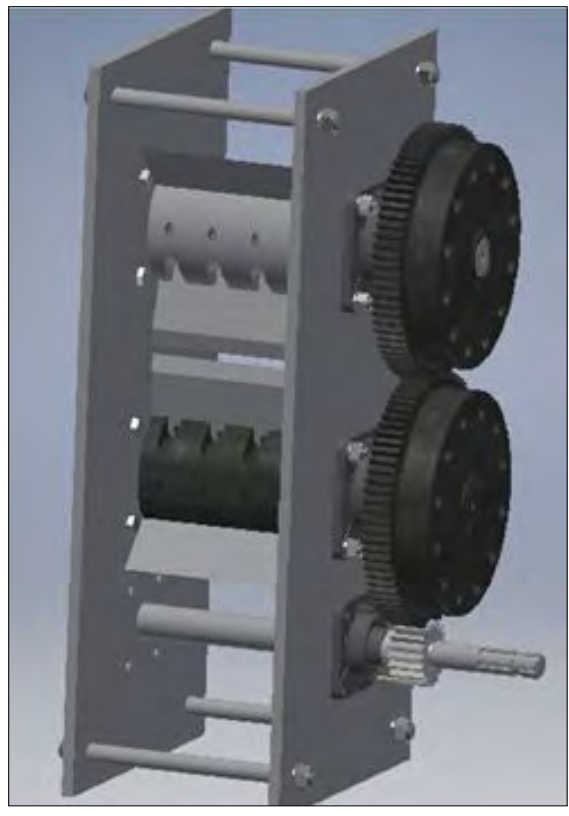

Figure 1.3D model of the wood cutting machine

conditions the position of the drive shaft does not change in relation to the spline shaft, furthermore we choose the dynamic loading conditions. The allowed surface compression of the spline shaft is $30-50 \mathrm{~N} / \mathrm{mm}^{2}$. [3]

Equation (1) calculates the maximum torque under these conditions as:

$$
\begin{aligned}
T & =0.75 \cdot \psi \cdot\left(\frac{D-d}{2}-2 \cdot f\right) \cdot l \cdot r k \cdot z \cdot p m e g \\
T & =526.246 \mathrm{Nm}
\end{aligned}
$$

where [3]

0.75 - means the ribs will be grinded after annealing.

$\Psi$ - is the dynamic factor,

$\mathrm{D}$ - outer diameter,

$\mathrm{d}$ - inner diameter,

$\mathrm{f}$ - chamfer of the ribs,

1 - length of the ribs,

rk - medium radius,

$\mathrm{z}$ - number of ribbs,

pmeg - allowed surface compression pressure.

Based on the above calculation the selected spline shaft withstands the loading.

\subsubsection{Blade holding shafts}

The material of the blade holding shafts is C45. The gear containing 78 teeth is connected by a sink key joint, and held in position by a washer and an M14 screw that is screwed into the end of the shaft. Three blades are placed into the milled 


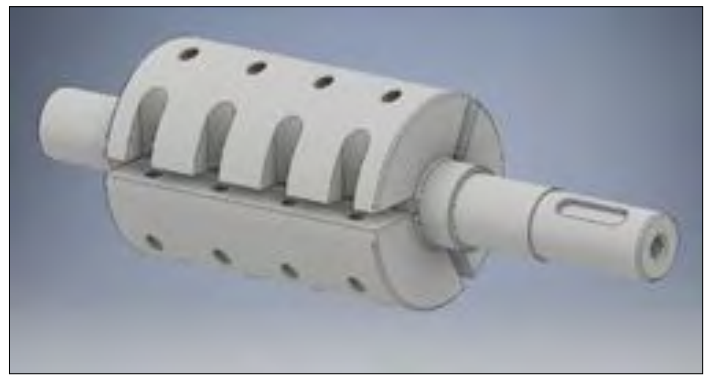

Figure 2. Blade holding shaft

pocket (13 $\mathrm{mm}$ wide and $50 \mathrm{~mm}$ deep) and positioned to $120^{\circ}$. Each blade is fixed to the shaft by $3 \mathrm{M} 12$ screws.

The third shaft is similar to the second shaft, the only difference being the direction of the milled pockets, since this shaft rotates to the opposite direction. The shafts were checked for torsion loading at the smallest diameter, and the verifying calculations confirmed that the shaft could withstand the applied maximum torsion loads. [4]

\subsubsection{Blades}

The blades are manufactured from high carbon content steel, annealed to 55-57 HRC. The $12 \mathrm{~mm}$ thick, $250 \mathrm{~mm}$ long and $132.5 \mathrm{~mm}$ wide blades are fixed to the $13 \mathrm{~mm}$ wide milled pockets of the shafts by four M12 screws. In order to fix the blades to the shafts $13 \mathrm{~mm}$ wide and $20 \mathrm{~mm}$ long pockets were milled to the shafts perpendicular to the blade holding pockets, as shown on Figure 2. The $20 \mathrm{~mm}$ length of the pockets serve the purpose of providing the ability to modify the distance between opposite blades after honing. In order to be able to control precisely the distance between the blades of the two shafts each blade is equipped with special positioning screws.

In order to provide extended lifetime for the blades, the design calls for a $30^{\circ}$ chamfer and annealing.

\subsubsection{Keys}

The dimensional design of keys are typically done by checking for surface pressure loading. [5]

We used the type A key from DIN 6885. [6] The length of the key is determined by the following equations:

$$
\begin{aligned}
& l=\frac{2 \cdot M t}{(d+h-t 1) \cdot(h-t 1) \cdot z \cdot p m e g} \\
& l f=l+b
\end{aligned}
$$

where:

$\mathrm{l}$ - length of the parallel sides,

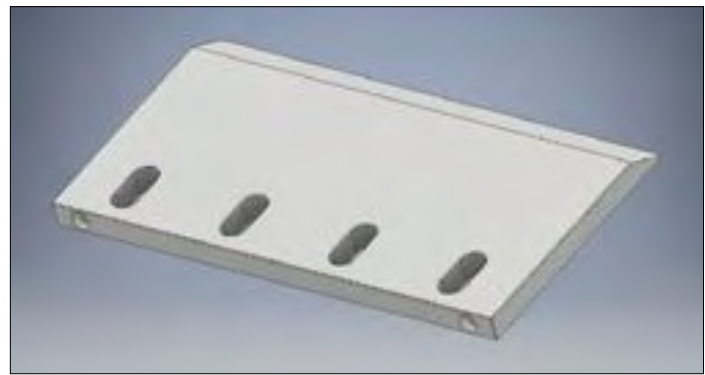

Figure 3. Blade

Mt - torque,

$\mathrm{d}$ - the diameter of the shaft,

$\mathrm{h}$ - height of the key,

$\mathrm{z}$ - number of keys used,

t1 - depth of the key hole on the shaft,

pmeg - the allowed surface pressure.

We have selected the worst case scenario for the surface pressure from the allowed interval, in this way over-dimensioning the key. The minimal length that is required is marked with lf, containing the rounded parts of the key, whereas $b$ is the width of the key. We have chosen the value of if from a specific table in such a way that the value is equal or higher than the calculated lf value. Based on the results we have selected the following keys: DIN 6885 - A10 x 8 × 32 - C45 K for the spline shaft and DIN 6885 - A16 x 10 x 63 -C45 K for the key holding shafts. [7]

\subsubsection{Bearings}

The shafts are loaded with radial forces, thus radial bearings are needed. We need to select a bearing that had a larger inner diameter than the gears, since the gears need to be supported by the bearing. The inner diameter of the gear is 52,3 $\mathrm{mm}$, and the closest bearing inner diameter is 55 $\mathrm{mm}$.

In most cases the bearing housing is formed in the side plate, which would imply the use of at least a $28 \mathrm{~mm}$ thick steel plate, made of high-quality material. The easiest way to manufacture such a plate would be metal casting, however that is a very expensive way. In order to reduce the cost and also provide an easily fixable solution we have selected the UCF type bearings shown in Figure 4. This type of bearing comes with a housing that can be mounted to the side plates with 4 screws. Due to the radial forces on the shafts, shearing loads will appear on the screws connecting the bearing housing to the side plates.

One additional benefit of this type of bearing housing is that it allows the twist of the outer ring 


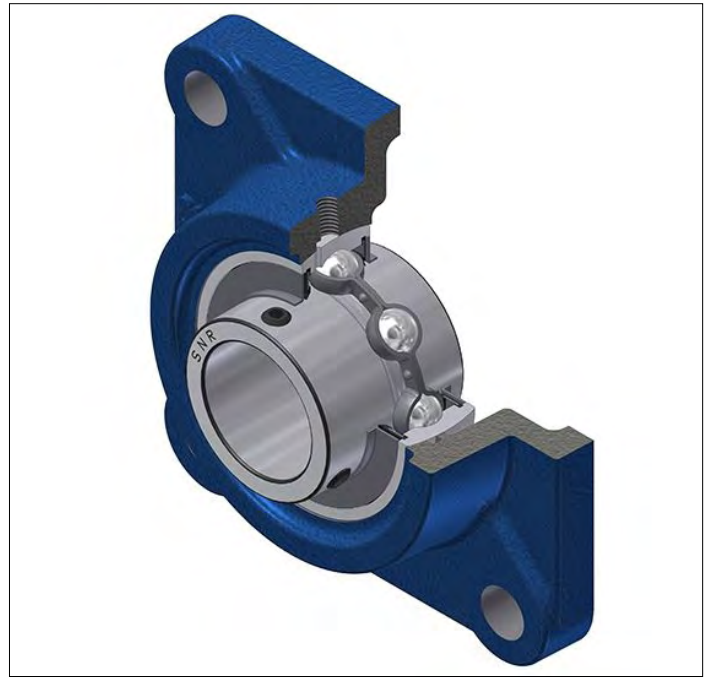

Figure 4. UCF-type bearing [8]

of the bearing in the housing, thus the bearing would not experience additional forces introduced by the imperfect part dimensions due to manufacturing precision. This solution also provides the easy replacement of the bearings in case of failure

\subsubsection{Gears}

The gears were originally used in a crane application, and now they are reused to build the wood cutting machine. The gears have an $\mathrm{m}=4.25 \mathrm{~mm}$ module and based on preliminary calculations they can withstand the resulting loads.

\subsubsection{Covering components}

In order to provide a sufficiently safe working environment around the wood cutting machine cover plates will be used. The moving part will be covered by $2 \mathrm{~mm}$ thick steel sheets so that the flying wood parts would not pose a threat to the machine handler and also prevent the touching the moving parts. A funnel is necessary to allow the feeding, and furthermore the gears will also be covered

\section{Conclusions}

This work presents the working principles, design steps and 3D model of a wood cutting machine. The designed machine has a robust structure, is driven by a tractor and designed with a cost-effective mindset and easy fixability. The machine is capable of cutting small diameter (15 $\mathrm{mm}$ ) wood pieces and branches into $20-30 \mathrm{~cm}$ length pieces in an effective and efficient way.

Based on the dimensioning calculations for the maximum torque provided by the tractor, all of the parts are capable of withstanding the loading resulting from the wood cutting procedure.

We are considering safety as the first priority, thus the machine is equipped with shielding components that cover the machine and protect the operator.

\section{References}

[1] Universal, D115. (accessed on: $21^{\text {th }}$ February 2019) https://www.scribd.com/document/228945425/ Reglaje-Motor-D115-U445-550.

[2] DIN 7968: Hexagon fit bolts for steel structures. 2007.

[3] Zsáry Á.: Tengely - agy kötések. Bordás tengelykötések. In: Gépelemek I. (Szerk.: Zsáry Á.). Nemzeti Tankönyvkiadó Rt., Budapest, 1999. 213-216.

[4] Antal A., Pop D., Oltean I. E. F.: Elemente constructive privind proiectarea arborilor. Capete de arboare cilindrice. In: Reductoare (Szerk.: Antal A.). Lito UTCN, Cluj Napoca, 1994. 141-143

[5] Antal B., Tolvaly-Roșca F.: Gépelemek 1, Egyetemi jegyzet, Sapientia Erdélyi Magyar Tudományegyetem, 2008.

[6] DIN 6885: Reteszkötések, 2008.

[7] Frischherz A., Dax W., Gundelfinger K.: Gépelemek. Reteszek. In: Fémtechnológiai táblázatok. (Szerk.: Frischherz A.). B + V Könyvkiadó KFt., 1997. 206.

[8] NTN-SNR Prémium csapágyak webáruháza: UCF 308 (accessed on: 20 $0^{\text {th }}$ February 2019). https://www.ntnsnr.hu/ucf308_30067 